\title{
Dental alginate impression waste as additional fertilizer for plant yields and soil quality
}

\author{
Tommy Frahdian*, Zulia Hasratiningsih*, Elin Karlina*, Diyan Herdiyantoro**, Veni \\ Takarini* \\ *Department of Ilmu dan Teknologi Material Kedokteran Gigi, Fakultas Kedokteran Gigi Universitas \\ Padjadjaran, Indonesia \\ **Department of Agrotechnology, Fakultas Agrotechnology Universitas Padjadjaran, Indonesia
}

\begin{abstract}
Introduction: Dental alginate impression material is the most common material used in dentistry. However, dental alginate waste (DAW) is one of the causes of the increasing number of dentistry and medicinal wastes. This research was aimed to discover the effect of dental alginate impression waste as additional fertiliser on the plant yields by determining the weight of cauliflower crop, and towards the quality of soil by determining the soil $\mathrm{pH}$ (Ultiso ${ }^{\oplus}$ Jatinangor). Methods: The experiment was using a randomised block design with 4 treatments and 7 times replications. The treatment consisted of $A_{0}(0 \%$ DAW as control), $A_{1}(0.01 \% \mathrm{DAW}), \mathrm{A}_{2}(0.1 \% \mathrm{DAW})$, and $\mathrm{A}_{3}(1 \% \mathrm{DAW})$. Results: The weight of cauliflower after addition of DAW in group $A 0$ was $72.78 ; A_{1}$ was 139.82 ); $A_{2}$ was 130.69 ; and $A_{3}$ was 60.72 ). While the $p H$ soil in group $A_{0}$ was $5.92 ; A_{1}$ was $6.07 ; A_{2}$ was 6.02 ; and $A_{3}$ was 6.26. The treatment in the $A_{1} \& A_{2}$ groups were found as the significant doses that able to increase the cauliflower weight for consecutively 1.92 times and 1.80 times compared to the control group, while on the soil quality improvement (soil pH), the addition of DAW was not significantly affected. Conclusion: It can be concluded that the addition of dental alginate waste at the dose of $0.01 \%$ and $0.1 \%$ increased the weight of cauliflower, but has no significant effect on the soil quality.
\end{abstract}

Keywords: dental alginate waste, plant weight, soil quality

P-ISSN 1979-0201, e-ISSN 2549-6212 Available from:http://jurnal.unpad.ac.id/pjd/article/view/16231

DOI: https://doi.org/10.24198/pjd.vol30no1.16231

Submission: Dec 2017 Publishing: Mar 2018

\section{INTRODUCTION}

Dental health services is one source of medical waste contributor. In quantity, the amount of waste generated by dental practice is very large, especially when calculated from the total number of dental health services in Indonesia. In 2013, Indonesia has 27 dental schools and thousands of dental practices are deployed. In dental service of Universitas Padjadjaran Dental Hospital (RSGM Unpad) the use of dental alginate impression can reach $900 \mathrm{~kg}$ per month, also more

Corresponding author: Tommy Frahdian, Department of Ilmu dan Teknologi Material Kedokteran Gigi, Fakultas Kedokteran Gigi Universitas Padjadjaran, Indonesia; M: +62 877-2274-8551; email:frahdiantommy@yaho.com. 
schools and dentist clinics can increase the use of dental alginate. ${ }^{2}$ The use of dental alginate as impression materials in the practice of dentistry is widely used because of the ease of stirring and manipulation, the necessary equipment is simple, the flexibility of the mold, accuracy, and the relatively economist. ${ }^{3,4}$

According to a study by Wulandari on the dumping of medical waste in individual dentistry in Bandung, waste derived from dental alginate molds was disposed of in the garbage along with other infectious waste and further disposal united with domestic waste. This suggests that dental alginate mold waste was treated improperly and not recycled. ${ }^{\prime}$

Test chemical content of dental alginate molds showed sufficient quantity to add nutrients associated with soil fertility and crops. The high calcium content of dental alginate waste in the amount of $25886,36 \mathrm{ppm}$ can be used as calcification material to improve soil quality ${ }^{5}$, also plants require macro and micro nutrients for their growth. Other nutrient derived from dental alginate waste were Nitrogen, Natrium, Phosphat, Kalium, Calsium, Mangan and Sulfur can support crop yields well. ${ }^{6}$ With the amount of potential contained in the dental alginate waste, researchers want to investigate the effect of adding dental alginate waste to the quality of soil and plant yields.

\section{METHODS}

The material used in this research were dental alginate waste obtained from Universitas Padjadjaran Dental Hospital, which has been through the process of washing, drying and meshing until the size approximately 2-3 mm (Fig. 1). The soil used was ultisol soil (acid soil) taken from 0-30 cm depth composite in Jatinangor area. The plants used were cultivar Sakata flower with the use of recommended fertilizers, ie urea, SP-36 fertilizer, $\mathrm{KCl}$ fertilizer and compost, also the use of pesticides and fungicides to prevent plant pests and diseases.

The tool used in this research were hoe, polybag, paper label, plastic bucket, water hose, hand sprayer, analytical scale and $\mathrm{pH}$ meter. Experiments were using 7 samples of $0 \%$ dental alginate waste (DAW) samples $\left(A_{0}\right)$ as control and 3 treatment groups $\left(A_{1}, A_{2}\right.$, and $\left.A_{3}\right)$ with 7 replications each. The $A_{1}$ treatment group used

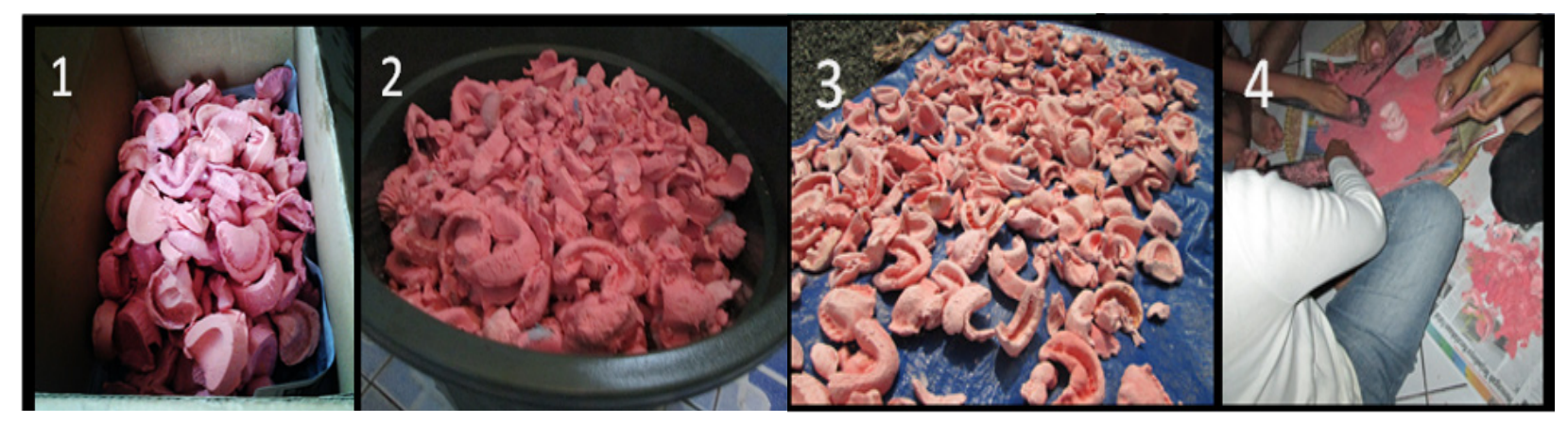

Figure 1. Dental Alginate Wastes Preparation
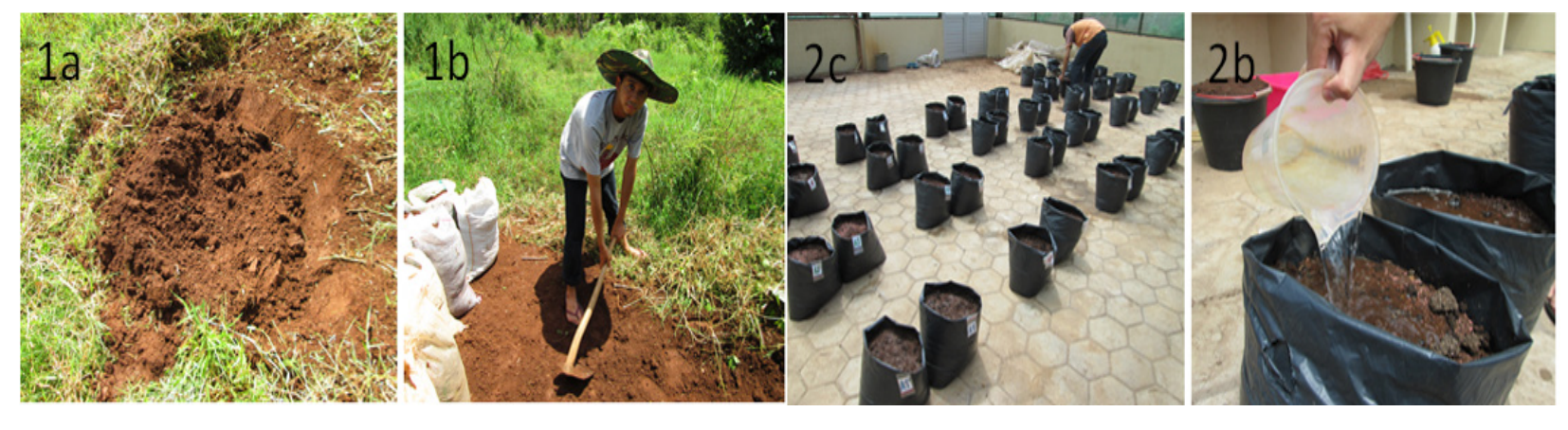

Figure. 2. Plant Media Preparation 
0.01\% DAW, $A_{2}$ treatment group used 0.1\% DAW and $\mathrm{A}_{3}$ treatment group used 1\% DAW.

The variables measured in this study were soil quality ( $\mathrm{pH}$ soil) and the weight of cauliflower yields influenced by the utilization of dental alginate wastes (DAW) and Ultisol Jatinangor soil. Soil quality was measured by soil ph condition and associated to the fertility, which nutrient contained inside the soil could be absorbed by the plant well. The weight gain by cauliflower plants showed the effect of DAW as additional plant fertilizer. The research involved preparation of plant media with composite soil taking at a depth of $0-30 \mathrm{~cm}$ from the surface of the soil, dried, cleaned from grass, crushed and filtered into polybag with 28 polybags (Fig. 2). Furthermore, the application of dental alginate wastes that has been prepared before, then mixed with soil in polybags and give the dose in accordance with the treatment at - 7 day after planting with the soil evenly. Polybag is placed in a greenhouse with a distance of $60 \mathrm{~cm} \times 60 \mathrm{~cm}$. Then seeds preparation using 2-week-old Sataka cultivar flowers seeds (leaf 5-6 strands).

Fertilization using recommended dosage of basic fertilizer used was urea fertilizer as much as $220 \mathrm{~kg}$ ha-1, SP-36 $311 \mathrm{~kg}$ ha-1, KCl 225 kg ha-1 and 10 tons ha- 1 compost. The fertilizers were applied to a single hole beside the plant $(7.5 \mathrm{~cm}$ away from the plant) and covered with soil. Urea fertilizers were given $88 \mathrm{~kg}$ ha-1 (at planting time = 0 day after planting), $44 \mathrm{~kg}$ ha-1 (14 day after planting), $44 \mathrm{~kg}$ ha-1 (21 day after planting) and $44 \mathrm{~kg}$ ha-1 (28 day after planting). SP-36 fertilizer of $311 \mathrm{~kg}$ ha-1 was given at planting time, $\mathrm{KCl}$ fertilizer was given $90 \mathrm{~kg}$ ha-1 when planted), $45 \mathrm{~kg}$ ha-1 (14 day after planting), $45 \mathrm{~kg}$ ha-1 (21 day after planting) and $45 \mathrm{~kg}$ ha-1 (28 day after planting) (Fig 3).

Compost fertilizer was given at -7 day after planting by mixing it evenly into the soil. Plant maintenance includes watering, weeding, pest and plant diseases control. The volume of water was the volume of water added to achieve the moisture content in the field capacity. Pest and diseases control were done by insecticide and fungicide spray, in accordance of its intensity. The last procedure was done by harvesting the cauliflower on 47 days plant with the soil sample and the result of the plant.

\section{RESULTS}

The main investigation in this study included soil quality with soil pHmeasurements and the weight of cabbage flower plants. the results of the cauliflower plant weight can be seen in Chart 1, as well as the photos of the plants according to the treatment can be seen in Figure 4.

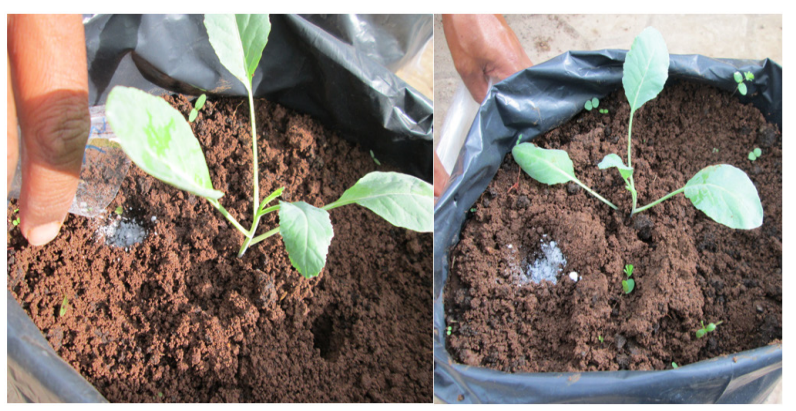

Figure 3. The recommended fertilizers using urea, SP-36, and $\mathrm{KCl}$
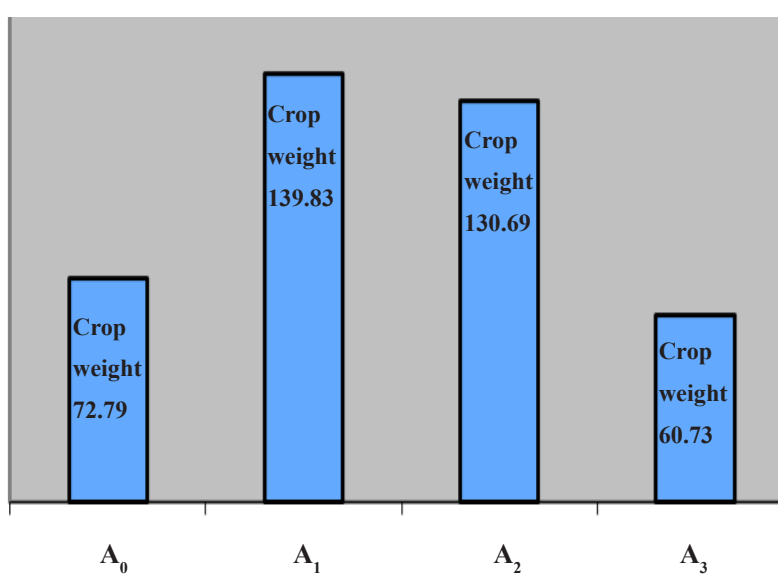

Grafic 1. Dosage of dental alginate waste on cauliflower crop weight

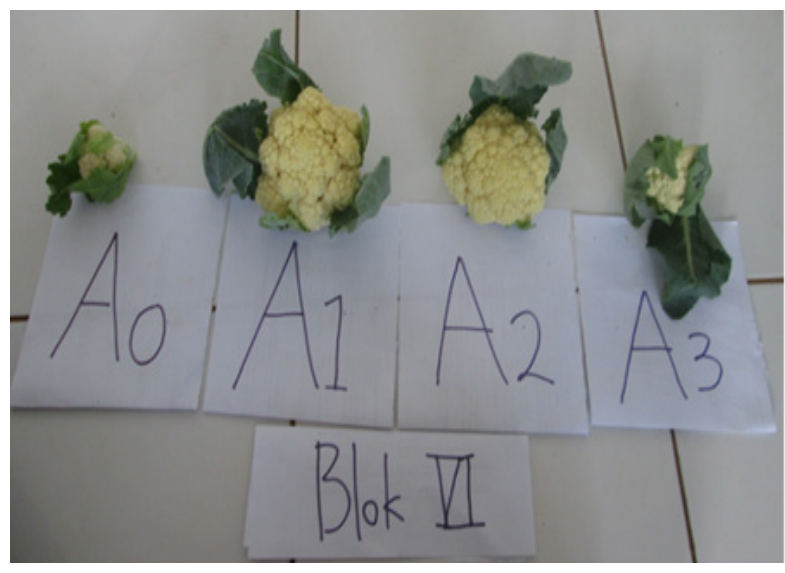

Figure. 4. Cauliflower crop results 


\section{DISCUSSION}

Growth is the result of some metabolic processes that occur in the body of a plant. Observation of the growth of a plant is an important part of a study so that the growing growth of the plant can be seen. Observation of growth and development of plants is a reflection of the condition of planting media fertility. One of the factors that influence fertility is the availability of nutrients contained in the planting medium. The availability of nutrients is influenced by the nutrient composition of the media that can affect the growth of plants so that plants can grow optimally. ${ }^{7}$ If the nutrients available in the medium are low, the plant will exhibit certain growth symptoms (according to nutrient deficiency symptoms), whereas if nutrients are available in sufficient quantities then the plants will grow well and optimally. Plant height is influenced by nutrient availability and nutrient uptake by plant roots. In this case the root plays an important role because the root serves as a nutrient absorber and the translocation of elements from root to stem, leaf, or fruit. ${ }^{8}$

Dosage of dental alginate waste (treatment group $A_{1}$ and $A_{2}$ ) tended to increase plant weight compared with treatment group $\mathrm{A}_{0}$ and $\mathrm{A}_{3}$. The stem is part of the plant that serves as a nutrient transport place which is then translocated by phloem from the leaves to the entire plant tissue. The diameter of the stem is the influence of the medium of plant growth. ${ }^{9}$ In addition to the development of stems, plants also require leaves for the process of photosynthesis and other processes that can support the optimum growth. ${ }^{10}$

The increase in plant weight, stem diameter and number of leaves is seen because the dental alginate waste contributes some nutrients needed by plants such as Nitrogen, Natrium, Potassium, Kalium, Calsium, Mangan and Sulfur. One of the N elements functions for plants is to improve growth vegetative plants. In addition, $\mathrm{Ca}$ contained in dental alginate waste has a function to assist the preparation of plant cell walls, cell division, growth and elongation. ${ }^{10}$

Bacteria such as Salmonella sp. and E coli was contained in the dental alginate waste. The result of bacterial test showed the number of Salmonella spp. and E coli respectively $2.6 \times 104$ $\mathrm{cfu} / \mathrm{ml}$ and $1.6 \times 105 \mathrm{cfu} / \mathrm{ml}$. In Permentan No.
70/Permentan/SR.140/10/2011, it is stipulated that the fertilizer or soil enhancer must meet the criteria of contaminant Salmonella spp. and E coli with a maximum number of less than 103 $\mathrm{cfu} / \mathrm{ml}$. This is intended to keep the contaminants of the bacteria population does not contaminate groundwater which is utilized by the community as a source of water. Plant pathogen microbes are organisms that cause disease in plants. Microbial pathogens can cause disease by consuming plant cell contents, killing or disrupting plant cells, weakening plants by sucking cell contents, and blocking vascular tissue. One of the plant pathogen microbes is bacteria. Groups of bacteria that cause disease in plants include Pseudomonas, Xanthomonas, Erwinia, Corynobacterium, Agrobacterium, Aplanobacter, Clostridium and Streptomyces. ${ }^{11}$

Based on statistical test, adding dental alginate waste on Ultisol Jatinangor soil gives significant increase of crop weight of cauliflower. Cauliflower plant given treatment with $0.01 \%$ and $0.1 \%$ dental alginate waste composition and recommended base fertilizer had the highest mean value of crop weight compared with control treatment $(0 \%$ DAW). Treatment with the composition of $1 \%$ dental alginate waste had the lowest mean value of crop weight. High crop yields due to nutrient needs in sufficient plants. ${ }^{10}$

The results of the plants correlate closely with the level of soil fertility through the availability of essential macro nutrients. ${ }^{12}$ Dental alginate waste contains macro nutrients such as $\mathrm{N}, \mathrm{P}, \mathrm{K}, \mathrm{Ca}, \mathrm{Mg}, \mathrm{Na}$ and $\mathrm{S}$ so that dental alginate waste can increase the availability of macro nutrients needed by plants that can ultimately increase crop yields. The availability of nutrients to be absorbed by plants is influenced by soil moisture, aeration, physical properties, and soil chemistry. Therefore the condition is suspected to be influenced by optimal nutrient content in the composition of the media. ${ }^{9}$

The nitrogen content $(\mathrm{N})$ contained in DAW is $0.14 \%$. According to Kresnatita et al. (2009) the increase of $\mathrm{N}$ content in planting medium will affect the crop, however $\mathrm{N}$ nutrient in plant tissue is only $2-4 \%$, therefore $\mathrm{N}$ content contained in DAW is one of nutrient content that can increase crop yield. . $^{8,10}$

The content of phosphorus $(P)$ found in DAW is $0.38 \%$ in the form of P2O5. P content is a useful 
nutrient in the formation of flowers, fruits and ores also useful in cell division, formation of albumin, accelerate maturation, strengthen stems, and root development. Optimal content of $\mathrm{P}$ in flower cabbage plants resulted in increased crop yield..$^{6,10}$ The potassium content $(\mathrm{K})$ contained in DAW is $1.12 \%$. The function of $K$ in plants is to form starch, activate enzyme, stomatal opening, physiological process in plants, metablik process in cells, affect other elements, enhance resistance to drought and disease, and assist in root development. Increasing the $\mathrm{K}$ content in the soil, causing the plant to grow well and crop yields can increase. ${ }^{10}$ The content of calcium ( $\mathrm{Ca}$ ) contained in alginate dentistry waste is $25886,36 \mathrm{ppm}$. Ca content for plants is useful in the preparation of plant cell walls, cell division, growing and elongation. In addition $\mathrm{Ca}$ element also as liming agent to increase soil reacting $\mathrm{pH}^{6,6,10}$

The magnesium content $(\mathrm{Mg})$ found in the dental alginate mold waste is $23262,16 \mathrm{ppm}$. The $\mathrm{Mg}$ content of the plant functions in the formation of chlorophyll, activator of plant enzyme system and oil formation. Sodium content $(\mathrm{Na})$ is a micro nutrient plays a complex role in the nutrients of plants, especially in the plant enzyme system. This element is involved in the movement of water (osmosis) and the balance of ions in the plant. $\mathrm{Na}$ content from dental alginate waste can support plant growth and impact on crop yield. The content of sulfur (S) contained in dental alginate waste is $0.96 \%$. S content for plants functions in protein formation. ${ }^{6,10}$

The treatment of $1 \%$ of dental alginate waste produced the lowest crop weight and this was supported by low plant height on the treatment. The lowest crop weight shown in the $1 \%$ treatment was due to the suspected presence of phosphorus binding $(\mathrm{P})$ by high iron content $(\mathrm{Fe})$ to form Fe-P bonds so that the $\mathrm{P}$ element became unavailable to the plant. In addition, phosphorus binding may also occur by calcium ( $\mathrm{Ca}$ ) forming $\mathrm{Ca}-\mathrm{P}$ bonds in which $\mathrm{Ca}$ can be donated by dental alginate waste at high doses (1\% DAW). According to Hardjowigeno (2003) the $\mathrm{P}$ element for the plant may become unavailable when bound by $\mathrm{Fe}$ on soils reacting sourly or bound by $\mathrm{Ca}$ on alkaline reacting soils. The unavailability of this $P$ element is thought to be the cause of low weight gain on the cauliflower plants. ${ }^{10}$
In the determination of soil quality improvement, based on statistics, the addition of dental alginate waste in Ultisol Jatinangor did not give significant increase to soil $\mathrm{pH}$. The dosage of dental alginate waste of $1 \%$ has a mean value of soil $\mathrm{pH}$ which tends to be higher than that of other dosage. The increase in soil pH depends on the dosage of the limiting agent administered. The higher of the chalk contained in the soil, the greater $\mathrm{pH}$ value had. Calcification is carried out by administration of $\mathrm{Ca}$ elements (can be calcium carbonate, calcium magnesium carbonate, $\mathrm{CaO}$, etc.) in fine form. ${ }^{10}$

\section{CONCLUSION}

The use of dental alginate waste which doses $0,01 \%$ (A1 treatment) and $0,1 \%$ ( $\mathrm{A} 2$ treatment) was significantly increase the cauliflower weight each 1,92 times and 1,80 times compared to the control. In the other side the use of dental alginate waste did not improve the soil quality (soil $\mathrm{pH}$ ) significantly.

\section{REFERENCES}

1. Bahtiar, Tenrirawe A, editors. Balai penelitian tanaman serealia. identifikasi hama utama jagung dan cara pengendaliannya pada tingkat petani di sulawesi selatan. Prosiding Seminar Ilmiah dan Pertemuan Tahunan. Prosiding, Seminar Ilmiah dan Pertemuan Tahunan XVI, 2005. p. 229-34. Sulawesi Selatan: Perhimpunan Entomologi Indonesia dan Perhimpunan Fitopatologi Indonesia, Komisariat Daerah Makasar.

2. Craig RG, Powers JM. Restorative Dental Materials. $11^{\text {th }}$ ed. St Louis Mo: The C.V. London: Mosby Company, 2002. p. 332-6.

3. Usri K. Jumlah Sekolah Kedokteran Gigi Semakin Banyak.[home page internet]. Indonesia: Dentamedia copyright $\odot$ 1997-2008. [cited April 2008];[about 3 screens]. Dentamedia Okt-Des 2008;12(4). Available from: http:// dentamedia.blogspot.com/2008/09/tes21. html.

4. Gardner FP, Pearce RB, Mitchell RL. Fisiologi Tanaman Budidaya. Jakarta: Universitas Indonesia (UI Press). Terjemahan: Susilo dan Subiyanto. (P) LTD.; 1991. p. 428. 
5. Hardjowigeno S. Ilmu tanah. Jakarta: CV. Akademika Pressindo. (P) LTD 2010. Avaliable From: https://www. belbuk.com/ilmutanah-p-16452.html\#ulasan.

6. Hardjowigeno S. Klasifikasi tanah dan pedogenesis. Akademika pressindo. Jakarta: Akademika Pressindo (P) LTD.;2003. Avaliable From: http://onesearch.id/Record/IOS3504. libra-086312216001175\#holdings.

7. Hardjowigeno S. Ilmu tanah. Akademika Pressindo, Jakarta: Pressindo. (P) LTD.; 2003

8. Jeddy. Pengaruh empat macam perlakuan pada bahan cetak alginat terhadap perubahan dimensi. Dentika Dent J 2001;6(1):1-5

9. Munawar A. Kesuburan tanah dan nutrisi tanaman. Bogor: IPB Press. (P) LTD.; 2011. p. 250 Avaliable From: https://www. belbuk.com/kesuburan-tanah-dan-nutrisitanaman-p-43350.html.

10. Rochdjatun I. Ilmu penyakit tumbuhan. Surabaya: Usaha Nasional. (P) LTD.; 1986.

11. Rosmarkam A, Yuwono NW. Ilmu kesuburan tanah. $7^{\text {th }}$ ed. Yogyakarta: Kanisius (Anggota IKPAI).;2002 Avaliable From: https://books. google.co.id/s?id=VOKq3mulYkkC\&pg=PP1\&d $\mathrm{q}=$ Rosmarkam\&hl=id\&sa=X\&ved=0ahUKEwjcgc
b9lY7aAhUIT48KHYf4BogQ6AEIJZAA\#v=onepag e\&qdf $=$ false.

12. Sarief S. Ilmu Tanah Pertanian. $1^{\text {st }}$ ed. Bandung: CV Pustaka Buana (P) LTD.; 1986. p. 157. Avaliable Form: http://library.umy.ac.id/ katalog.php?opo=lihatDetilKatalog\&id $=5617$.

13. Suradji MS. Dasar-dasar IImu penyakit tumbuhan. Jakarta: Penebar Swadaya (P) LTD.; 2003. p. 153. Avaliable Form: https:// books.google.co.id/books/about/Dasar_ dasar_ilmu_penyakit_tumbuhan.html?id=U_ mGNwAACAAJ\&redir_esc $=\mathrm{y}$.

14. Suyono AD. Kesuburan Tanah dan Pemupukan. Bandung: RR Print (P) LTD.; 2006.

15. Wulandari CY. Production rate and composition of general private dental practice waste (case study bandung city 2008) [minor thesis]. Bandung : Institut Teknologi Bandung; 2008.

16. Yuliana A. Pengaruh Kombinasi Media Tanam Abu Vulkanik Merapi, Pupuk Kandang Sapi, dan Tanah Mineral Inceptisols terhadap N Total, C Organik, Rasio C/N, Serapan N Tanaman, Populasi Azotobacter sp dan Bobot Kering Brangkasan Tanaman Jagung Hibrida (Zea mays) Varietas BISI 16 [minor thesis]. Jatinangor: Universitas Padjadjaran.; 2012. 